\title{
RANCANGAN SISTEM INFORMASI PENGADAAN BARANG PADA PT. INDALUX ENTERPRINDO DENGAN METODOLOGI BERORIENTASI OBYEK
}

\author{
Candra Tri Wahyudi' ${ }^{1)}$, Dian Anubhakti ${ }^{2)}$ \\ ${ }^{1}$ Sistem Informasi, Fakultas Teknologi Informasi, Universitas Budi Luhur \\ 1,2 Jl. Raya Ciledug, Petukangan Utara, Kebayoran Lama, Jakarta Selatan 12260 \\ E-mail : candra3wahyudi@gmail.com ${ }^{1)}$, dian.anubhakti@budiluhur.ac.id ${ }^{2)}$
}

\begin{abstract}
Abstrak
PT. Indalux Enterprindo adalah perusahaan system integrator, sebagai penunjang kualitas kinerja karyawan maka difasilitasi dengan adanya pengadaan barang namun yang saat ini dilakukan masih secara manual dan menyebabkan hasil dari kinerja kurang maksimal, hal tersebut akhirnya menimbulkan penumpukan berkas, pencarian data yang membutuhkan waktu, memungkinkan terjadi percatatan dan perhitungan yang tidak sesuai, serta laporan pengadaan barang yang dibuat terlampau lama. Untuk menghindari terjadinya potensi kesalahan data dan pembuatan laporan yang dilaporkan menjadi tepat, maka sistem komputerisasi pengadaan barang adalah solusi utama. Dengan penerapan berorientasi obyek, penelitian ini mampu menghasilkan sebuah rancangan sistem informasi pengadaan barang pada PT. Indalux Enterprindo. Penelitian ini diharapkan mampu menjadi hasil dan juga solusi bagi permasalahan dalam hal pengadaan barang pada PT. Indalux Enterprindo.
\end{abstract}

Kata kunci: Sistem informasi, pengadaan barang, berorientasi obyek

\section{PENDAHULUAN}

Tidak dapat dipungkiri lagi bahwa Teknologi Informasi/Sistem Informasi (TI/SI) dalam perusahaan ataupun institusi menjadi suatu kebutuhan yang wajib dimiliki dalam membangun kinerja yang baik dalam segala sisi serta perkembangan yang ada. Perusahaan maupun institusi untuk dapat berkompetisi dengan pesaingpesaingnya membutuhkan Teknologi Informasi/Sistem Informasi sebagai nilai tambah dan keunggulan dalam berbisnis. Pengadaan barang merupakan investasi di bidang SI yang sangat penting untuk perkembangan sebuah perusahaan atau lembaga dalam menunjang sebuah proses bisnis yang transparan dan terbuka. Tujuan penulisan laporan ini yang dilaksanakan di P.T. Indalux Enterprindo adalah memberikan perbaikan pada existing system yang telah ada, dan mencari solusi terbaik, dan memberikan kemudahan dalam terjadinya proses pengadaan barang. Diharapkan dengan adanya sistem pengadaan barang yang dilakukan dapat memberikan hasil informasi yang mutu, tepat dan akurat. Serta pada akhirnya sistem ini dapat meningkatkan efektifitas kerja para karyawan dan membantu dalam menyelesaikan masalah yang sering terjadi pada sistem yang ada saat ini. Berdasarkan wawancara kepada purchasing staff PT. Indalux Enterprindo, ternyata sistem pengadaan barang yang ada saat ini masih diolah secara manual dan kegiatan pengadaan barang yang berjalan saat ini belum memiliki integrasi yang baik antar bagian, data yang disimpan masih dalam bentuk word dan excel. Sehingga didapati permasalahan-permasalaha seperti rangkapnya pencarian data permintaan barang karena semakin berkembangnya kegiatan perusahaan maka pengolahan data jumlahnya semakin meningkat namun penyimpanan masih dilakukan secara manual, Data penerimaan barang sering kali sulit ditemukan, pengadaan barang yang sudah dilakukan sulit untuk dicari datanya, informasi penerimaan barang yang dikirimkan dari supplier sulit ditemukan. Yang menyebabkan harus mencari-cari dokumen penerimaan barang terlebih dahulu, informasi yang dibutuhkan pimpinan dalam bentuk laporan terkait atas data barang yang diretur ke supplier tidak tersedia, sehingga pimpinan tidak memiliki informasi yang benar atas retur tersebut, dan tidak tersedianya informasi berapa besar biaya pengadaan yang dikeluarkan untuk setiap bagian sehingga pimpinan tidak dapat mengontrol besaran biaya yang dikeluarkan

Sebagai batasan masalah dalam penelitian sistem pengadaan barang ini agar tidak menyimpang dari pokok permasalahan maka peneliti menyampaikan beberapa hal yang menjadi ruang lingkup dengan tujuan untuk menghindari kesalahan pengertian terhadap pembahasan yaitu proses permintaan barang dari Unit kerja/Cabang, proses pemesanan barang ke supplier, proses pengirimnan barang dari supplier dan proses pembuatan laporan.

Sistem dapat dimaksudkan adalah sebagai satu kesatuan dari kelompok elemen-elemen yang saling berinteraksi. Konsep umum untuk sistem adalah kelompok komponen yang berhubungan satu sama lain, bekerja sama demi mencapai tujuan yang sama 
dengan menerima input serta menghasilkan output dalam proses transformasi yang teratur [1]. Suatu sistem mempunyai karakteristik atau sifat-sifat. Karakteristik sistem adalah sebagai berikut : Komponen Sistem (Component), Batasan Sistem (Boundary), Lingkungan Luar Sistem (Environments),Penghubung Sistem (Interface), Masukan Sistem (Input), Keluaran Sistem (Output),Pengolahan Sistem (Process) danSasaran Sistem (Objective or Goal)[2].

Informasi adalah sebuah hasil dari pengolahan data yang memiliki kegunaan dan berarti bagi penerimanya[3]. Informasi ini terdiri atas data-data, namun demikian informasi dapat didefinisikan berbeda dengan data. Fakta dan juga angka yang sedang tidak digunakan dalam proses pengambilan keputusan yang biasanya berbentuk catatan sejarah yang dicatat dan diarsipkan tanpa adanya maksud untuk diambil kembali sebagai pengambilan keputusan merupakan definisi dari sebuah data.

Suatu sistem yang mempertemukan kebutuhan pengelolaan transaksi harian, serta menjadi pendukung operasi, bersifat manajerial, dan dapat menyediakan laporan-laporan yang dibutuhkan dan dipergunakan dalam kegiatan strategi dalam organisasi adalah sebagai definisi dari sistem informasi [3].

Analisa sistem merupakan tahapan awal dari sebuah perancangan sistem, yang harus memiliki gambaran yang jelas tentang yang terjadi pada analisa sistem maka selanjutnya adalah tentang bagaimana membentuk sistem tersebut. Perancangan sistem adalah suatu fase dimana keahlian dalam merancang dari elemen-elemen komputer yang digunakan pada sistem dalam pemilihan peralatan dan program komputer untuk sistem yang baru [4].

Strategi dalam pembangunan perangkat lunak yang mengorganisasikan perangkat lunak sebagai kumpulan obyek-obyek yang berisikan data serta operasi yang diberlakukan kepadanya[5].

\section{PENELITIAN SEBELUMNYA}

Penelitian yang dilakukan oleh Sugeng Santoso, Tia Maryani, dan Desaf Putri Rosmana yang berjudul Perancangan Sistem Informasi Persediaan Barang untuk Mengetahui Jumlah Stok Barang pada Warehouse Fitting PT. Surya Toto Indonesia TBK, Tangerang Selatan yang dipublikasikan pada Seminar Nasional Multi Disiplin Ilmu. Perusahaan ini harus memperhatikan persediaan barang non inventory (komodity) pada bagian warehouse fiiting, sistem saat ini pada pencatatan barang masih manual sehingga jumlah barang yang ada di Microsoft Office Excel berbeda dengan jumlah yang ada di warehouse fitting.
Dengan perancangan sistem informasi persediaan barang yang diusulkan untuk stok barang pada warehouse fitting di PT.Surya Toto Indonesia Tbk. Tangerang Selatan menggunakan CSF (Critical Succes Factor) sehingga terwujudnya sistem yang baik dalam pihak yang terkait dalam memonitoring barang non inventory (komoditi) dan memwujudkan kelancaran dalam melaksanakan pekerjaan.[6]

\section{METODE PENELITIAN}

Dalam penelitian ini, metode yang digunakan untuk mengumpulkan data adalah dengan dilakukan observasi, wawancara, dokumentasi, dan studi pustaka. Setelah itu dilakukan analisis proses dan analisis masalah. Activity diagram digunakan untuk menggambarkan analisa proses dengan menggunakan teknik penggambaran logical procedure, business process dan juga jalur kerja [7] . Analisis masalah digambarkan dengan fishbone diagram. Berdasarkan analisis masalah dan identifikasi kebutuhan, kemudian dilakukan perancangan sistem sebagai solusi atas permasalahan yang dianalisis pada tahapan sebelumnya. Fungsifungsi yang diusulkan digambarkan dengan use case diagram. Desain model basis data digambarkan dengan Entity Relationship Diagram.

\subsection{Analisa Proses}

1. Proses permintaan barang

Pada gambar 1, Permintaan barang didasarkan dari kebutuhan barang Dari pemohon yang tercantum pada form permintaan barang (FPB), form ini wajib dibuat dari pemohon yang membutuhkan barang. Form permintaan diserahkan ke Purchasing Staff, jika barang yang diminta tersedia maka PurchasingStaff menyiapkan barang dan membuatkan Bukti Serah Terima Barang(BSTB), BSTB ditanda tangani oleh penerima dan yang menyerahkan.Jika barang yang diminta Dari Bagian teryata barang tidak tersedia,purchasing staff akan membuatkan pesanan barang ke Supplier dengan menyertakan Purchase Order(PO) lalu mengirimkan PO tersebut kepada Supplier.

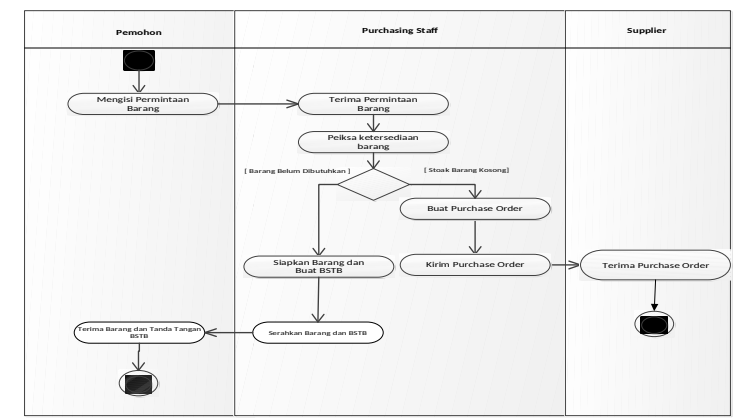

Gambar 1. Activity diagram permintaan barang 


\section{2. $\quad$ Proses penerimaan barang}

Pada gambar 2, Supplier mengirimkan barang disertai dengan dokumen Delivery Order(DO), lalu dokumen tersebut ditujukan ke Purchasing Staff, Purchasing Staff melakukan pengecekan terhadap barang yang telah sampai tersebut dan disesuaikan antara barang dengan dokumen DO, selain barang dan DO,Supplier biasanya menyertakan juga Invoice. Purchasing Staff akan mengembalikan barang yang apabila pada saat pengecekan terdapat barang yang rusak atau tidka sesuai dengan pesanan. Apabila barang yang dikirm sudah sesuai dengan Purchase Order maka Purchasing Staff akan menandatangani Delivery Order yang diterima dan langsung dibuatkan tanda terimanya.

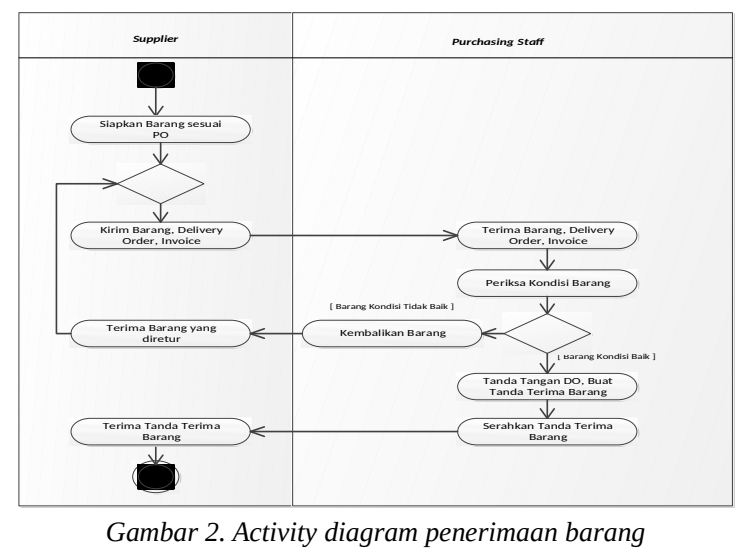

3. Proses pembayaran

Pada gambar 3, setelah barang diterima, Supplier akan mengirimkan Invoice sebagai rincian jumlah pembayaran yang harus dibayarkan perusahaan atas pembelian barang yang dikirimkan oleh Supplier ke Purchasing Staff, pembayaran dilakukan secara transfer bank sesuai rekening dari supplier.

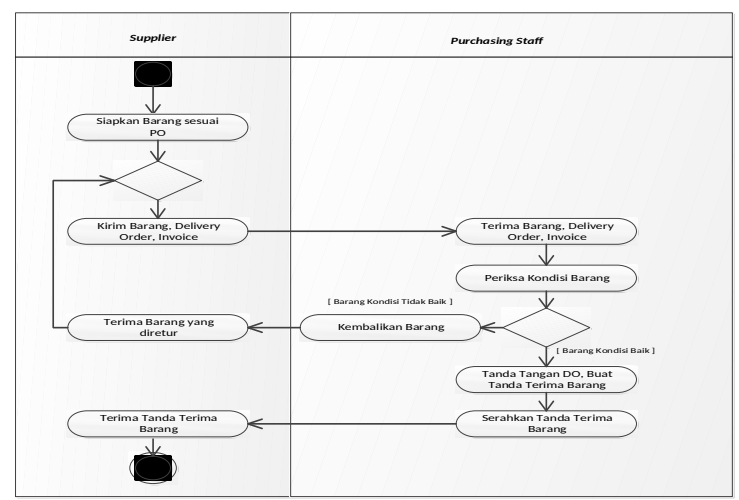

Gambar 3. Activity diagram pembayaran

4. Proses retur barang

Pada gambar 4, Retur barang terjadi jika barang yang telah kita terima lalu akan digunakan ternyata bermasalah, maka barang akan di retur ke Supplier, Purchasing Staff akan menghubungi pihak Supplier untuk memberikan informasi bahwa barang tidak dapat digunakan lalu barang akan diambil oleh Supplier dan menggantinya dengan barang baru.

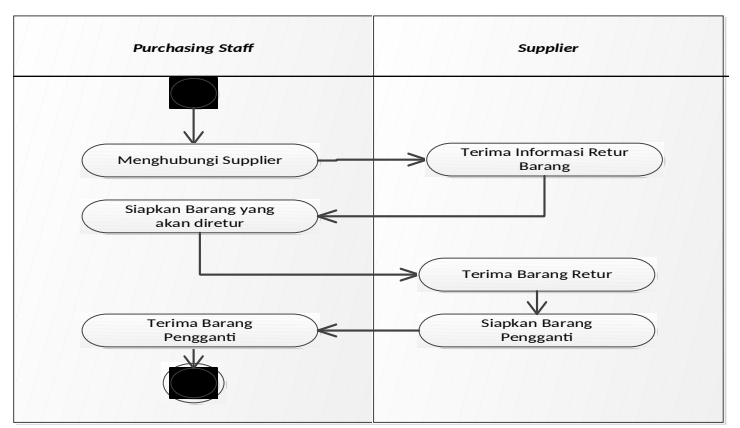

Gambar 4. Activity diagram retur barang

5. Proses pembuatan laporan

Pada gambar 5, Purchasing staff setiap akhirbulan akan membuat laporan dari pekerjaan pengadaan barang yang terjadi. Serta melakukan perekapan data yang diminta oleh direktur.

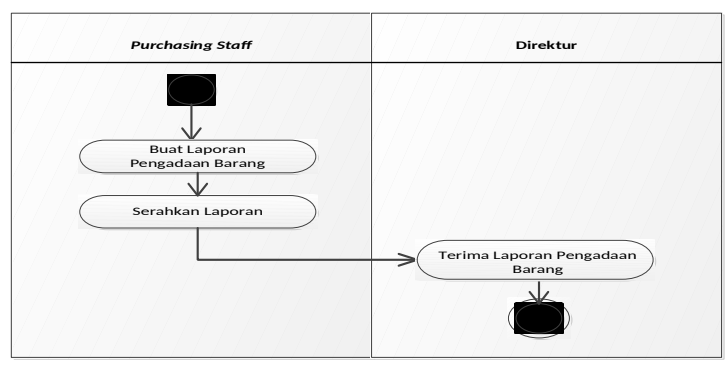

Gambar 5. Activity diagram pembuatan laporan

\subsection{Analisa Masalah}

Pada tahapan ini, permasalahan dalam pengadaan barang pada PT. Indalux Enterprindo dapat di kategorikan seperti Tempat, Proses, Manusia dan Informasi. Pada gambar 6 merangkum detail permasalahan disetiap kategori.

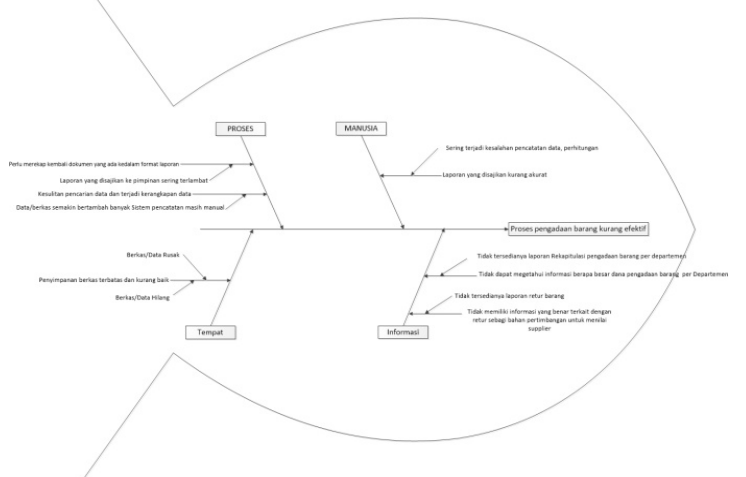

Gambar 6. Fishbone diagram 


\subsection{Usecase Diagram}

Berikut usulan yang dapat menjadi solusi atas permasalahan pada PT. Indalux Enterprindo tentang beberapa fungsi dan fitur. Pada gambar 7 dikelompokan beberapa fungsi untuk menginput data master yaitu, data barang, data supplier, data bagian dan data pemohon.

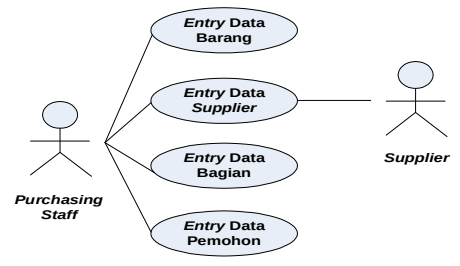

Gambar 7. Usecase diaaram entrv data

Sedangkan untuk transaksi pengadaan barang disajikan pada Gambar 8. Pada gambar tersebut dapat dilihat bahwa ada fungsi untuk mengentry data permintaan barang, mencetak berita acara serah terima barang, mengentry tanda terima barang, mengentry pembayaran barang, mencetak puschase order, mencetak surat retur barang, serta mengupdate status retur barang.

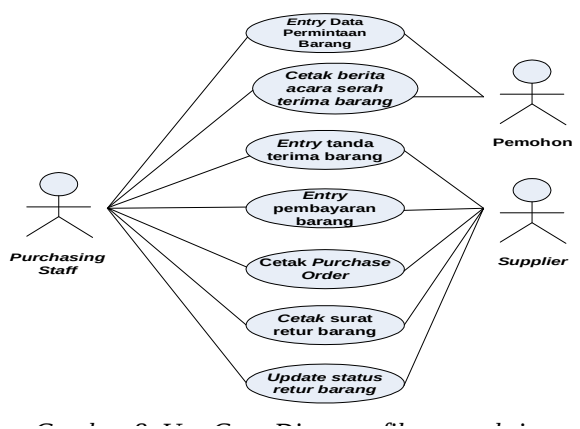

Pada gambar 9 digambarkan beberapa fungsi pencetakan laporan per-periode : yaitu cetak laporan permintaan barang, cetak laporan penerimaan barang, cetak laporan pengadaan barang, cetak laporan serah terima barang, cetak laporan retur barang dan cetak laporan rekapitulasi pengadaan barang.

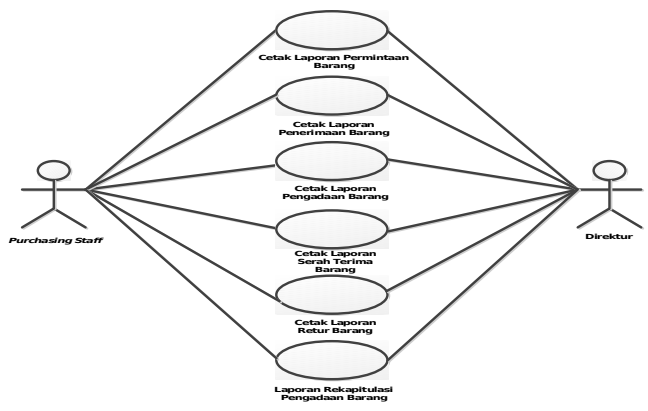

Gambar 9. Use case cetak laporan
4. HASIL DAN PEMBAHASAN

4.1. Model Data

a. Entity-Relationship Diagram(ERD)

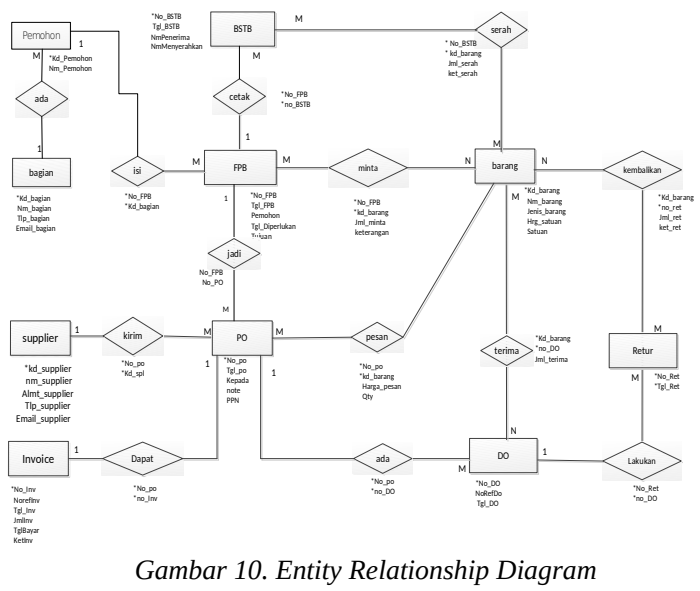

Entity Relationship Diagram memodelkan data apa yang ada, terlihat pada gambar 10 tujuan utamanya dari penggambaran ERD adalah menunjukkan object data (entitas) dan hubungannya (relationship) terhadap entitas yang ada sehingga dapat dihasilkan File-File yang ada akan dibentuk. Berikut ini akan dijelaskan langkah-langkah yang dilakukan dalam pembentukan ERD.

1. Tentukan entity-entity yang diperlukan

2. Tentukan relationship antar entity

3. Tentukan isi kardinalitas dan Primary Key dari tiap entitas

4. Tentukan atribut yang diperlukan di tiap entitas

5. Pemetaan atribut, memasang atribut dengan satu entitas yang sesuai

6. Gambar entity relationship diagram dengan atribut

7. Periksa hasil, hindari penamaan entity, relationshiprelationship dan atribut yang sama

b. Transformasi ERD ke LRS

Pada gambar 11 dan 12, transformasi ERD ke Logical Record Structure (LRS) adalah kegiatan pembentukan data dari ER-Diagram ke dalam bentuk LRS. Transformasi tersebut harus mengikuti langkah-langkah sebagai berikut :

1. Transformasi $(1: 1)$ One to one:

Pilih salah satu entity yang mau ditransformasikan dengan entity yang berbeda dalam satu cardinality, transformasikan ke entity yang membutuhkan referensi atau ke entity yang mempunyai jumlah atribut lebih sedikit

2. Transformasi $(1: \mathrm{M})$ One to many atau $(\mathrm{M}: 1)$ Many to one :

Pilih ke arah many untuk mentransformasi, tidak perlu melihat jumlah atribut yang lebih sedikit, 
selalu digabung ke arah many

3. (M : N) Many to many:

Relationship berdiri sendiri, tiap entity menjadi sebuah LRS dan relationship juga menjadi sebuah LRS
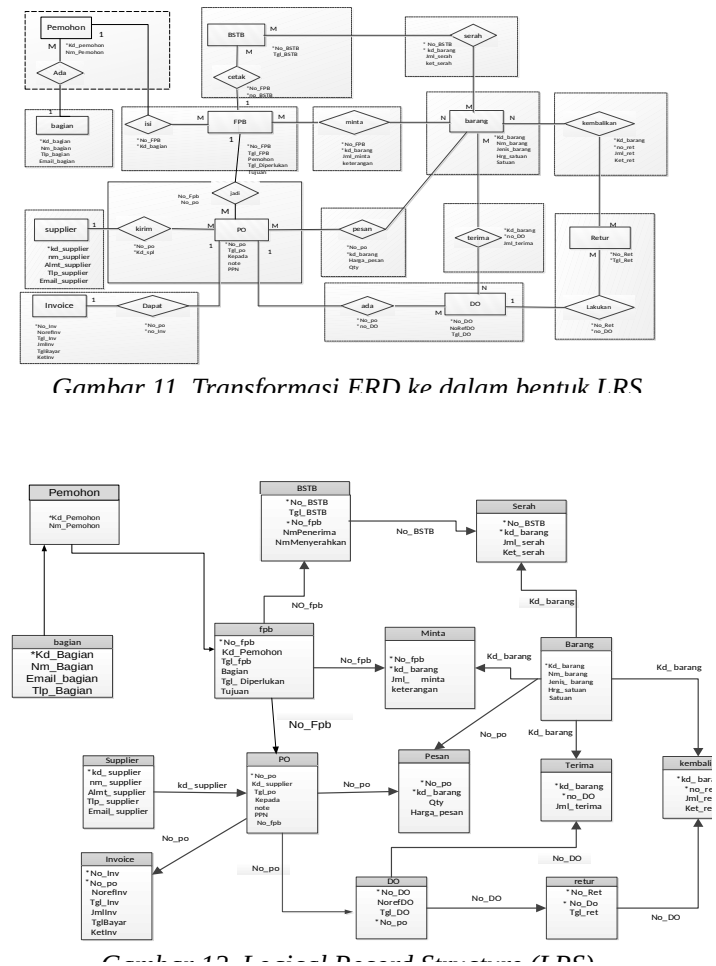

\subsection{Struktur Menu}

Fungsi-fungsi yang diusulkan pada Gambar 7, 8, dan 9 dijadikan pedoman dalam menentukan rancangan layar. Di setiap fungsi memiliki input dan atau output. Rancangan dari input dan output harus disesuaikan dengan identifikasi kebutuhan dan analisis dokumen yang ada pada existing system. Struktur tampilan layar sistem informasi pengadaan barang yang diusulkan, disajikan pada Gambar 13.

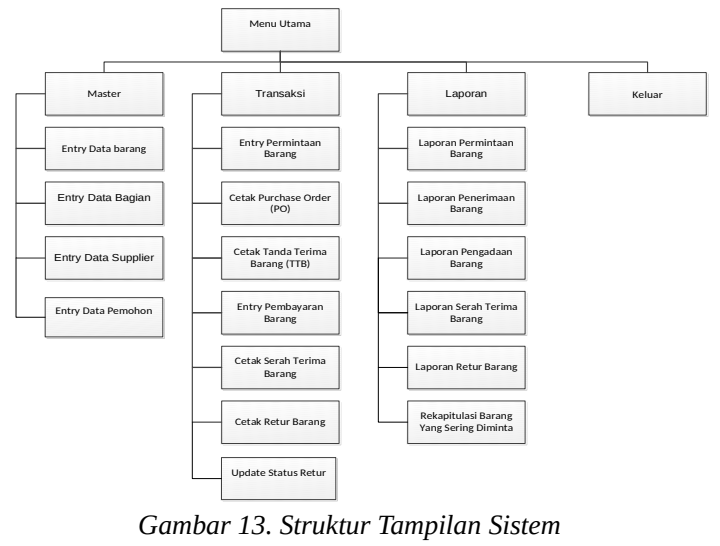

\subsection{Rancangan Layar}

1) Rancangan Layar Menu Utama
Menu utama terdiri dari menu Master, Menu Transaksi, Menu Laporan dan Keluar seperti pada gambar 14.

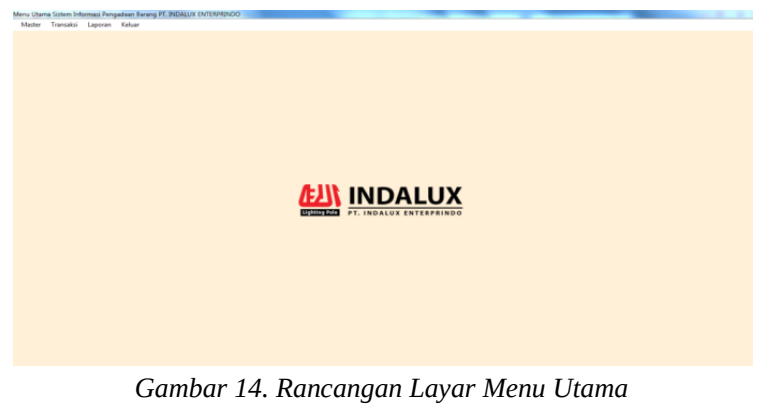

2) Rancangan Layar Menu Master

Pada gambar 15, Menu Master terdiri dari empat sub menu. Entry Data Barang, Entry Data Bagian, Entry DataSupplier, Entry Data Pemohon .

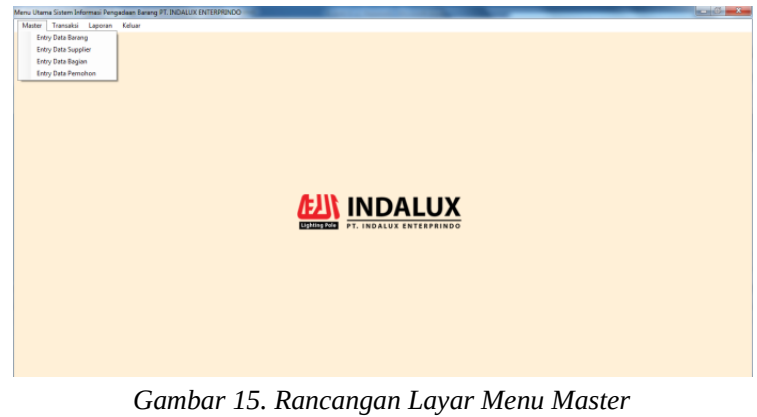

3) Rancangan Layar Menu Transaksi

Menu Transaksi terdiri dari tujuh sub menu pada gambar 16. Entry Permintaan Barang, Cetak Purchase Order (PO), Cetak Tanda Terima Barang (TTB), Entry Pembayaran Barang, Cetak Berita Acara Serah Terima Barang (BSTB) dan Cetak Surat Retur Barang, Update Status Retur.

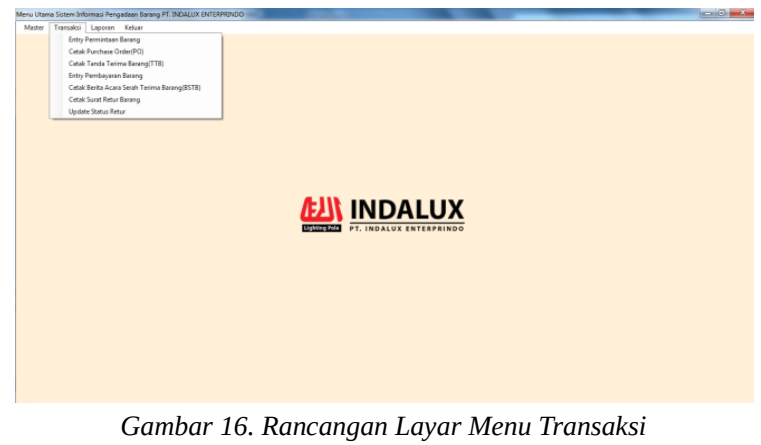

4) Rancangan Layar Menu Laporan

Menu Laporan pada gambar 17 terdiri dari enam sub menu. Cetak Laporan Permintaan Barang, Cetak Laporan Penerimaan Barang, Cetak Laporan Pengadaan Barang, Cetak Laporan Retur Barang, Cetak Laporan Serah Terima Barang dan Rekapitulasi Pengadaan Barang Per Bagian 


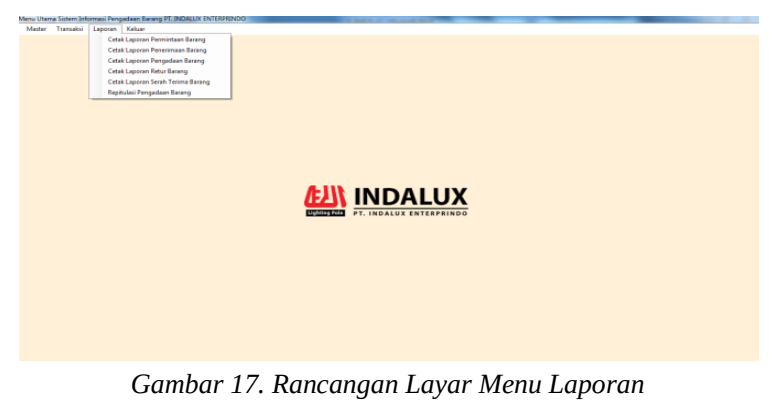

5) Rancangan Layar EntryData Barang

Form Entry Data Barang pada gambar 18 adalah form untuk memasukan data barang ke dalam Sistem Pengadaan Barang PT. Indalux Enterprindo. Form ini terdiri dari form isian, ubah, hapus dan pencarian data barang.

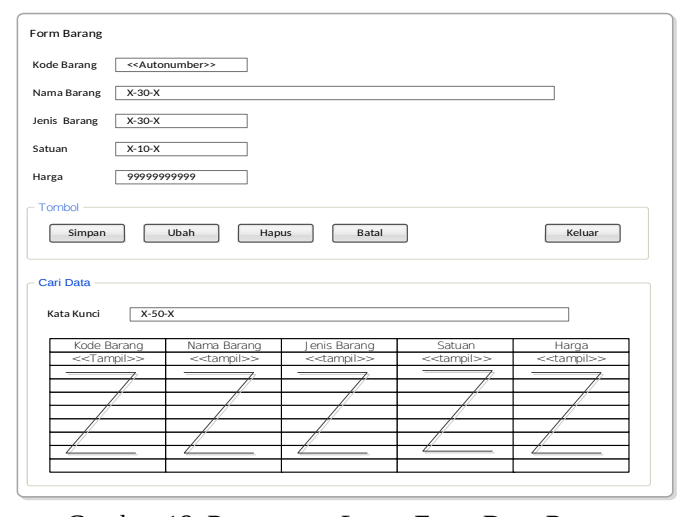

6) Rancangan Layar Entry Permintaan Barang Pada gambar 19 Form Entry Permintaan Barang digunakan untuk memasukan data permintaan barang Dari Bagian ke dalam Sistem Pengadaan Barang PT. Indalux Enterprindo. Terdapat form pencarian Data Bagian, detail pemohon dan detail barang yang diminta.

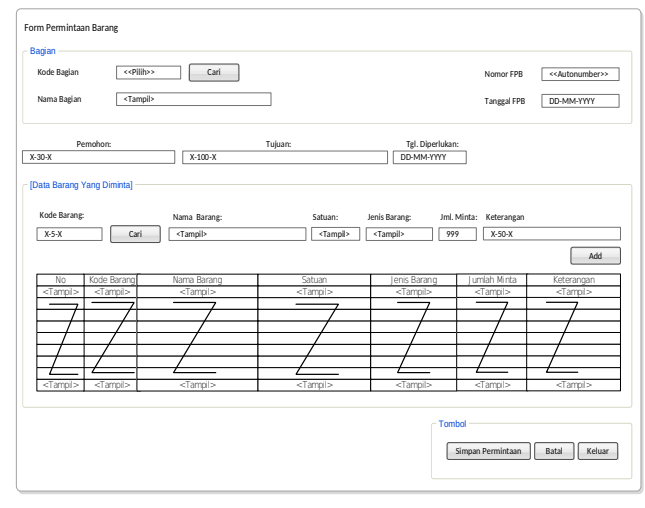

Gambar 19. Rancanaan Lavar Entrv Permintaan

7) Rancangan Layar Cetak Laporan Permintaan Barang
Form Cetak Laporan Permintaan Barang pada gambar 20 digunakan untuk mencetak Laporan Permintaan Barang berdasarkan periode tanggal yang dipilih.

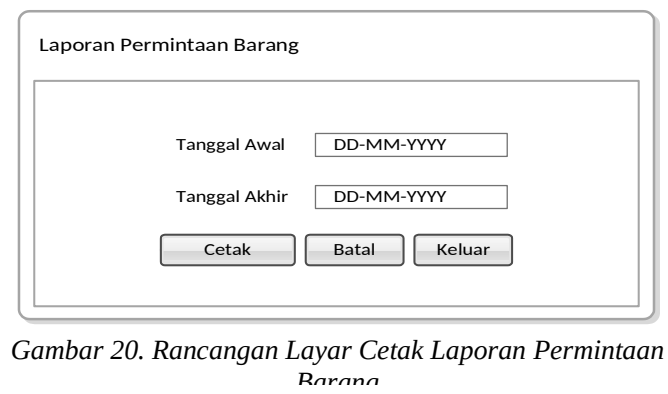

5. KESIMPULAN

a. Setelah dilakukan Dengan penggunaan sistem yang terkomputerisasi, maka dapat mempermudah pencarian data permintaan barang dalam bentuk fitur laporan permintaan barang serta dapat menghindari terjadinya kerangkapan data.

b. Pencarian data untuk penerimaan barang jauh lebih mudah dan efisien karena menggunakan sistem yang sudah terkomputerisasi dengan adanya fitur laporan penerimaan barang.

c. Dengan adanya fitur laporan pengadaan barang maka direktur lebih mudah untuk memantau proses pengadaan yang telah dilakukan.

d. Dengan tersedianya fitur laporan penerimaan barang, maka penerimaan barang dapat dilihat data lebih cepat dan akurat.

e. Fitur laporan retur menjadi suatu dokumen penting dan wajib dicatat kedalam sebuah sistem sehingga informasi retur barang jadi lebih jelas.

f. Dengan adanya fitur laporan rekapitulasi pengadaan barang dapat diketahui informasi besaran biaya yang dikeluarkan untuk pengadaan barang setiap bagian serta dapat disajikan sehingga direktur dapat mengontrol biaya yang dikeluarkan karena adanya sistem yang sudah terkomputerisasi.

\section{UCAPAN TERIMA KASIH}

Rasa terima kasih yang begitu dalam kepada Ibunda Supriyati tercinta yang mana telah mendukung dan memotivasi penulis dalam menyelesaikan jurnal ilmiah ini serta tidak lupa kepada pimpinan dan segenap staff PT.Indalux Enterprindo yang sudah memberikan kesempatan 
kepada penulis untuk melakukan riset pada perusahaan.

\section{DAFTAR PUSTAKA}

[1] Indrajani. Perencanaan Basis Data Dalam All in 1. Jakarta: Elex Media Komputindo. 2012.

[2] Sutabri, Tata. Analisis Sistem Informasi. Yogyakarta: Andi offset. 2012.

[3] Hutahaean, J. Konsep Sistem Informasi. Yogyakarta: Deepublish. 2014.

[4] Kristanto, Andri.. Perancangan Sistem Informasi Dan Aplikasinya. Yogyakarta: Gava Media. 2008.

[5] Rosa A.S, M. S. Modul Pembelajaran: Rekayasa Perangkat Lunak. Bandung: Modula. 2013.

[6] Santoso, S., Maryani,T. and Rosmana, D. Perancangan Sistem Informasi Persediaan Barang untuk Mengetahui Jumlah Stok Barang pada Warehouse Fitting PT. Suryo Toto Indonesia TBK. Tangerang Selatan. Seminar Nasional Multi Disiplin Ilmu,1,149-157. 2017.

[7] Fowler, Martin. UML Distilled 3th E, Panduan Singkat Bahasa Pemodelan Objek Standar. Yogyakarta: Andi. 2005 